\title{
Annotation
}

\section{Inhaled nitric oxide in neonates}

\section{Scientific foundation}

Nitric oxide (NO) is a major regulator of vascular smooth muscle tone. Generated enzymatically by one of several NO synthases from L-arginine, ${ }^{1} \mathrm{NO}$ activates guanylyl cyclase by binding to its haem component, ${ }^{2}$ leading to the production of cyclic GMP. ${ }^{34}$ This then relaxes vascular and bronchial smooth muscle by a mechanism which probably involves inhibition of an activation induced increase in cytosolic calcium concentration. ${ }^{5} \mathrm{NO}$ has a high affinity for the iron of haem proteins, including reduced haemoglobin, forming nitrosyl haemoglobin (NOHb), which is then oxidised to methaemoglobin with the production of nitrate. ${ }^{6}{ }^{7}$ As a result, when given as an inhalation, NO relaxes pulmonary vascular smooth muscle and is inactivated without altering the systemic vascular bed. NO mediates the reduction in pulmonary vascular resistance associated with birth..$^{8-10}$ Inhalation of NO, in a variety of animal models, is an effective, selective pulmonary vasodilator which improves ventilation perfusion matching. ${ }^{11}{ }^{12}$ In adults with severe respiratory distress syndrome treatment with inhaled nitric oxide (INO) reduced pulmonary arterial pressure and increased oxygenation secondary to a decrease in intrapulmonary shunting, ${ }^{13}$ with an improvement in oxygenation and a reduction in pulmonary vascular resistance (PVR) noted at INO doses as low as 1 ppm. ${ }^{14}{ }^{15}$ The clinical use of INO in neonates has mushroomed since the original reports by Roberts ${ }^{16}$ and Kinsella ${ }^{17}$ which demonstrated sustained improvements in oxygenation in hypoxic near term infants with persistent pulmonary hypertension (PPHN), using $80 \mathrm{ppm}$ and 20 $\mathrm{ppm}$ of INO, respectively. A subsequent preliminary dosing study did not demonstrate a significant dose effect in hypoxic neonates. ${ }^{18}$

\section{Prospective controlled trials in neonates}

As a result of these observations, a multicentre, multinational, prospective placebo controlled randomised trial was conducted to evaluate whether INO would reduce the incidence of death or the need for ECMO in neonates of 34 weeks gestation or greater with hypoxic respiratory failure (NINOS Study) ${ }^{19}$ Eligible infants required assisted ventilation with two oxygenation indexes $\left(\mathrm{OI}=\left(\mathrm{MAP} \times \mathrm{FIO}_{2} \times\right.\right.$ 100)/ $\mathrm{PaO}_{2}$ ) equal to or greater than 25. While echocardiograms were performed before randomisation, the diagnosis of PPHN was not a required inclusion criteria. This trial encouraged maximal conventional treatment before randomisation. Thus rescue surfactant treatment was given to over $70 \%$ of the enrolled infants; about $55 \%$ of infants were treated with high frequency ventilation; and over $90 \%$ of infants received blood volume support, vasopressors, sedation and/or analgesia, and muscle paralysis. Alkalosis was induced in over $75 \%$ of enrolled infants before randomisation with no differences observed in the use of such treatments between INO and placebo (oxygen) treated infants. The trial was terminated on 2 May, 1996 following the second planned review by the Data Safety Monitoring Committee at which time 235 of the planned 250 infants had been enrolled. Treatment with INO resulted in a significant reduction in the primary outcome (combined incidence of death $<120$ days or the need for ECMO) from $64 \%$ in control infants to $46 \%$ in INO treated infants; $\mathrm{P}=0.005, \mathrm{RR}=0.71,95 \%$ CI $0.56,0.90$. There was no difference in the occurrence of death (17\% of controls vs $14 \%$ of INO infants), and there was a significant reduction in the need for ECMO from $55 \%$ in control infants to $39 \%$ in INO treated infants $(\mathrm{P}=0.014) .{ }^{19}$ INO treatment resulted in a significant improvement in $\mathrm{PaO}_{2}\left(\Delta \mathrm{PaO}_{2}+59.6+85.6\right.$ vs $9+51.8, \mathrm{P}<0.001)$ and a significant fall in the $\mathrm{OI}$ $(-14.1+21.0$ vs $1+21.2, \mathrm{P}<0.001)$.

Other prospective controlled studies of near term infants with hypoxic respiratory failure and PPHN have been completed and the preliminary findings reported. Kinsella et $a l^{20}$ enrolled 205 ECMO candidates in a prospective randomised multicentre crossover clinical trial of HFOV (high frequency oxygen ventilation) and INO. This study found no difference in the need for ECMO or death in the INO group compared with the HFO group, and the authors suggested that combined treatment with INO and HFO may improve outcome. Wessel et a ${ }^{21}$ studied 49 neonates with PPHN of 34 weeks gestation or greater and reported that oxygenation was better in the NO group than in controls $(\mathrm{P}<.02)$. Roberts et al ${ }^{22}$ treated 50 term infants with PPHN and found that treatment with INO was more successful than conventional treatment in reducing the OI to less than 40 .

Published trials to date include that of Day et $a l,{ }^{23}$ who studied 22 infants with PPHN and OIs between 25 and 40 in a prospective randomised trial of INO, and also treated all infants who had, or developed, an OI of greater than 40 with INO. They found that INO was associated with improved oxygenation, especially in patients with minimal or focal lung disease, whereas infants with lung hypoplasia and severe diffuse lung disease on chest radiograph were less likely to show a favourable response. Goldman $e t a l^{4}$ described four patterns of response to INO, and similar to Day et $a l,{ }^{23}$ noted that infants who had a sustained fall in OI to less than 40 did well, whereas those infants whose OIs increased above 40 either died or, with one exception, required ECMO. They also noted a group of infants who responded but became dependent on higher doses of INO and died of pulmonary hypoplasia and dysplasia. We have seen a small number of infants who have failed to respond to lower doses of $\mathrm{NO}$ and who respond exclusively to high dose - 60 to $80 \mathrm{ppm}$ of INO-similar to those described by Goldman et al. ${ }^{24}$ In our experience a significant portion of such infants have fatal congenital abnormalities of their pulmonary vasculature, so called misalignment of the pulmonary veins or alveolar capillary block. ${ }^{25}{ }^{26}$ In contrast to the previous studies, no reduction in the need for ECMO was found in one other prospective randomised crossover trial of 17 neonates. ${ }^{27}$

\section{Congenital diaphragmatic hernia}

The NINOS pilot trial of term and near term infants with congenital diaphragmatic hernia $(\mathrm{CDH})$ enrolled 53 
infants and found that there was no significant difference in the occurrence of the primary outcome, death, and/or the need for ECMO between the INO and control groups, although INO infants required ECMO more frequently than control infants $(80 \%$ vs $53.6 \%, \mathrm{P}=0.043) .^{28}$

Other published case series have also noted a general lack of a sustained improvement in oxygenation in response to INO in the early management of $\mathrm{CDH}$, with occasional exceptions. ${ }^{29-33}$ Some infants seem to develop improved oxygenation in association with INO treatment used later in their disease course. ${ }^{30}$

\section{Premature infants}

Pulmonary hypertension is not unique to the full term infant, and Stahlman et al described raised pulmonary artery pressures in premature infants with significant respiratory distress over 20 years ago, ${ }^{34}$ a finding which has recently been reconfirmed by echocardiography. ${ }^{35}{ }^{36}$ We and others have reported a small number of premature infants who were treated with INO with significant improvements in oxygenation. ${ }^{37}{ }^{38}$ The preliminary results of a prospective study of INO on premature infants of less than 32 weeks gestation requiring mechanical ventilation reported that infants who received INO had a sustained fall in OI and a reduction in pulmonary artery pressure (PAP) (Subhedar et al, abstract presented at the British Neonatal Society, November 1996).In the study by Day et $a l^{23} 16$ infants of less than 36 weeks gestation responded similarly to the more mature infants treated in this study. Skimming et al administered either $5 \mathrm{ppm}$ or $20 \mathrm{ppm}$ INO to 20 premature infants of 28 weeks gestation with respiratory distress syndrome and reported significant increases in $\mathrm{PaO}_{2}$ at both doses. ${ }^{39}$ No prospective trials evaluating clinically important outcomes with adequate numbers of premature infants have been reported to date.

\section{Infants with congenital heart disease}

Infants with congenital heart disease and preoperative or postoperative pulmonary hypertension have been treated with INO using very low doses of INO to lower their pulmonary vascular resistance, ${ }^{40}{ }^{41}$ and to compensate for reduced pulmonary endothelial NO production following cardiopulmonary bypass. ${ }^{42}$ No prospective placebo controlled trials have yet been reported in infants with congenital heart disease.

\section{Other clinical considerations}

Clinicians who have treated significant numbers of neonates with INO will have observed the dramatic decrease in oxygenation seen in some infants when INO is discontinued, even if such infants have not had a dramatic initial improvement in their arterial oxygen concentrations. This response has been described in children ${ }^{44}$ and older patients ${ }^{45}$ and may reflect down-regulation of endogenous NO synthase activity secondary to the administration of exogenous NO. An alternate explanation may be that during exogenous NO treatment, cGMP specific phosphodiesterase may be increased. Following discontinuation of INO, therefore, the increased phosphodiesterase activity may continue to degrade endogenous NO resulting in vasoconstriction. Whatever the cause, INO should be cautiously weaned, with a reduction to very low doses (1 to 2 $\mathrm{ppm}$ ) before stopping the inhalation. A similar rebound effect in pulmonary artery pressure has been described in infants and children receiving NO for pulmonary hypertension following cardiac surgery. ${ }^{46}$ Such infants should continue to be carefully monitored for the next 1 to 2 hours and the clinician should be prepared to reinitiate treatment if clinical deterioration occurs.
If the response of an infant has been equivocal, especially if transportation is required for other treatments such as ECMO, a trial of withdrawal of INO before transport is indicated. If the infant deteriorates INO should be continued until other rescue treatments are directly available. INO can be safely administered during transport. ${ }^{47} 48$

Under rare circumstances INO may result in an acute clinical deterioration, such as in infants with ductal dependent systemic blood flow, or as the result of an unexplained paradoxical response. ${ }^{49}$ However, most infants not showing a significant improvement in oxygenation following treatment with INO do not show any deterioration associated with this treatment and, in fact, may have less physiological variability and clinical instability, possibly resulting from decreased pulmonary artery reactivity.

The monitoring of INO can be done using other chemiluminescence or electrochemical sensors, the latter tending to be somewhat smaller and more portable, and current iterations of either device provide for continuous and reasonably accurate monitoring of both $\mathrm{NO}$ and $\mathrm{NO}_{2}$. Continuous monitoring is required to avoid inadvertent increases in $\mathrm{NO}$ or sudden discontinuation of $\mathrm{NO}$ as a result of gas lines becoming disconnected or a loss of $\mathrm{NO}$ gas supply.

\section{Toxicity}

Nitric oxide reacts with oxygen to form nitrogen dioxide, $\mathrm{NO}_{2}{ }^{50}{ }^{51}$ Both $\mathrm{NO}$ and $\mathrm{NO}_{2}$ are toxic, causing death in dogs at concentrations between 0.1 and $2 \%$, due to methaemoglobinaemia, hypoxaemia, and pulmonary oedema; much lower concentrations of $\mathrm{NO}_{2}(17 \mathrm{ppm})$ produce changes in rat lungs. ${ }^{52-54}$ In humans exposure to $2.3 \mathrm{ppm}$ $\mathrm{NO}_{2}$ for five hours produced a $14 \%$ decrease in serum glutathione peroxidase activity and a $22 \%$ decrease in alveolar permeability 11 hours after the start of exposure, suggesting that even very low concentrations of $\mathrm{NO}_{2}$ may produce a delayed response. ${ }^{55}$ Occupational health guidelines set 25 ppm as the limit for 8 hours/day NO exposure in the workplace and $3 \mathrm{ppm}$ (measured as the time weighted average) as the limit for $\mathrm{NO}_{2}{ }^{56}{ }^{57}$ Bouchet et $a \bar{P}^{8}$ have shown that using $80 \mathrm{ppm}$ INO in a neonatal ventilator with an $\mathrm{FIO}_{2}$ of 0.9 could produce $5 \mathrm{ppm} \mathrm{NO} \mathrm{N}_{2}$ in less than 20 seconds.

Methaemoglobin concentrations must also be carefully monitored, and it is encouraging that, to date, there have been no reports of serious methaemoglobinaemia in spite of prolonged inhalation (up to 23 days for a neonate, ${ }^{16} 53$ days for an adult ${ }^{13}$ ).

When NO reacts with superoxide, peroxynitrite is rapidly formed and this can result in membrane lipid peroxidation. There is no human information to date with respect to the actual formation of such peroxynitrites in patients receiving INO, but the potential remains for resultant tissue injury, especially in the lung, ${ }^{59}$ with damage to surfactant and its related proteins. ${ }^{6061}$

NO inhibits platelet aggregation and adhesion and as such has an important role in vascular homeostasis. ${ }^{62}$ It is believed that INO does not exert systemic effects because of the previously mentioned interaction with haemoglobin, Hogman et al have reported increased bleeding times in rabbits and humans exposed to $30 \mathrm{ppm}$ of INO. ${ }^{63}{ }^{64}$ This is of concern especially if INO is proposed as treatment for critically ill, hypoxic premature infants at risk of intracranial bleeding who may have been already treated with indomethacin (to produce ductal closure), an agent that also inhibits platelet function.

\section{Related issues}

By decreasing PVR, INO has also been found to decrease transvascular albumin flux in the lung, which may be an additional benefit in treating adult RDS-like pulmonary 
disorders. ${ }^{65}$ NO may have a significant role in preventing reperfusion induced endothelial dysfunction and the associated increases in microvascular permeability by inhibiting neutrophil-endothelial cell activation and adhesion. ${ }^{66}$ Barbotin-Larrieu et al reported that INO during reperfusion of isolated ischaemic piglet lungs prevented increases in PVR and transvascular permeability and prevented the decrease seen in circulating neutrophils. ${ }^{67}$ Inhaled nitric oxide for more than 24 hours in human neonates resulted in a reduced superoxide anion production by $\mathrm{N}$-formyl-methionyl-leucylphenylalanine or $E$ coli stimulated neutrophils ${ }^{68}$ similar to results seen by Guidot et $a l^{69}$ in isolated rat lungs.

Interestingly, the nasal mucosa produces $\mathrm{NO}$, which is normally inhaled, and the normal newborn infant has concentrations of $\mathrm{NO}$ in the upper airway comparable with those of an adult. ${ }^{70}$ Endotracheal intubation bypasses the nasal airway and leads to decreased tracheal concentrations, ${ }^{71}$ which suggests that auto-inhalation of endogenous NO produced from the upper airway may be important in regulation of pulmonary blood flow and gas exchange.

As noted above, INO exerts its vasorelaxant properties by the production of cGMP. Inhibition of the specific phosphodiesterase which metabolises cGMP can enhance the vasorelaxation of INO. ${ }^{72}$ While the use of such treatment has already been reported, ${ }^{73}$ caution is required as phosphodiesterase inhibition is not selective and has the potential to alter systemic haemodynamics.

\section{Future questions}

Many questions are still to be answered. What is the lowest effective dose? We are, no doubt, currently well above the response threshold with current management, and the use of lower doses will reduce the likelihood of accumulations of methaemoglobin and $\mathrm{NO}_{2}$. Will the earlier use of INO result in better outcomes? Does pretreatment with surfactant improve the response to INO in humans as it seems to in some animal models? Is INO more effective during high frequency ventilation? Will improved or earlier treatments with more conventional modalities, including surfactant and high frequency ventilatory techniques, be as effective as INO? What is the appropriate role of INO in the premature infant? Does the loss of endogenously produced NO in intubated patients result in significant clinical morbidity and require replacement therapy? Should INO be used as a treatment even if it is only able to improve oxygenation or reduce PVR without improving clinical important outcomes? What is the role of INO in infants and children with cardiac disease and pulmonary hypertension, and what studies are required in this group to establish efficacy? Most importantly, what are the long term effects, if any, of INO on the developing lung and on the infant's neurodevelopment? Will NO prove to be safer and more effective than other inhaled pulmonary vasodilators $?^{74}{ }^{75}$ It may well be that we know more about INO treatment in neonates than many other current treatments, but that only serves to remind us that we repeatedly expose our most vulnerable patients to our most unproved treatments.

\section{Conclusions}

Inhaled nitric oxide is, at present, the only effective, selective, pulmonary vasodilator which has been established by prospective, randomised trials to reduce the need for ECMO in the near term infant with hypoxic respiratory failure. The lack of effect on systemic haemodynamics, coupled with the relative safety of administration, when appropriately monitored, would support the use of INO in preference to other systemically administered vasodilators, including prostacyclin and tolazoline. Similar prospective, multicentre, randomised trials are required to evaluate the benefit of INO in premature infants with hypoxic respiratory failure and should include a careful evaluation of the occurrence of intracranial haemorrhage in this population. One would hope that the introduction of INO for the premature infant in the United Kingdom would parallel the introduction of ECMO for the near term neonate and that, at present, such treatment should be given only within the context of an appropriately designed randomised control trial, such as the INNOVO study.

Department of Neonatology,

NEIL FINER

UCFD Medical Centre,

200 West Arbor Drive,

San Diego,

CA 92103-8774,

USA

email:nfiner@ucsd.edu

1 Palmer RMJ, Rees DD, Ashton DS, Moncada S. L-arginine is the physiological precursor for the formation of nitric oxide in endotheliumdependent relaxation. Biochem Biophys Res Commun 1988;153:1251-6.

2 Ignarro LJ, Adams JB, Horwitz PM, Wood KS. Activation of soluble guanylate cyclase by NO-hemoproteins involves NO-heme exchange. F BiolChem 1986;261:4997-5002

3 Burke-Wolin T, Abate CJ, Wolin MS, Gurtner GH. Hydrogen peroxideinduced pulmonary vasodilation: role of guanosine 3',5'-cyclic monophosphate. Am F Physiol 1991;261:L393-L8.

4 Gruetter CA, Gruetter DY, Lyon JE, Kadowitz PJ, Ignarro LJ. Relationship between cyclic guanosine $3^{\prime}: 5^{\prime}$-monophosphate formation and relaxation of coronary arterial smooth muscle by glyceryl trinitrate, nitroprusside, nitrite and nitric oxide: Effects of methylene blue and methemoglobin. f Pharmacol Exp Ther 1981;219:181-6.

5 Walter U. Physiological role of cGMP and cGMP-dependent protein kinase in the cardiovascular system. Rev Physiol Biochem Pharmacol 1989;113:42in the 88 .

6 Yoshida K, Kasama K. Biotransformation of nitric oxide. Environ Health Perspect 1987;73:201-6.

7 Wennmalm A, Benthin G, Petersson AS. Dependence of the metabolism of nitric oxide (NO) in healthy human whole blood on the oxygenation of its red cell haemoglobin. Br F Pharmacol 1992;106:507-8.

8 Abman SH, Chatfield BA, Hall SL, McMurtry IF. Role of endotheliumderived relaxing factor during transition of pulmonary circulation at birth. Am f Physiol 1990;259:H1921-H7.

9 Cornfield DN, Chatfield BA, McQuestion JA, McMurtry IF, Abman SH. Effects of birth-related stimuli on L-arginine-dependent pulmonary vasodilation in ovine fetus. Am F Physiol 1992;262:H1471-H81.

10 Kinsella JP, McQueston JA, Rosenberg AA, Abman SH. Hemodynamic effects of exogenous nitric oxide in ovine transitional pulmonary effects of exogenous nitric oxide in ovin

11 Pison U, Lopez FA, Heidelmeyer CF, Rossaint R, Falke KJ. Inhaled nitric oxide reverses hypoxic pulmonary vasoconstriction without impairing gas exchange. $\mathcal{F}$ Appl Physiol 1993;74:1287-92.

12 Putensen C, Rasanen J, Lopez FA. Improvement in VA/Q distributions during inhalation of nitric oxide in pigs with methacholine-induced bronchoconstriction. Am f Respir Crit Care Med 1995;151:116-22.

13 Rossaint R, Falke KJ, Lopez F, Slama K, Pison U, Zapol WM. Inhaled nitric oxide for the adult respiratory distress syndrome. $N$ Engl $f$ Med 1993;328:399-405.

14 Gerlach H, Rossaint R, Pappert D, Falke KJ. Time-course and dose-response of nitric oxide inhalation for systemic oxygenation and pulmonary hypertension in patients with adult respiratory distress syndrome. Eur f Clin Invest 1993;23:499-502.

15 Lowson SM, Rich GF, McArdle PA, Jaidev J, Morris GN. The response to varying concentrations of inhaled nitric oxide in patients with acute respiratory distress syndrome. Anesth Analg 1996;82:574-81.

16 Roberts JD, Polaner DM, Lang P, Zapol WM. Inhaled nitric oxide in persistent pulmonary hypertension of the newborn. Lancet 1992;340:81819.

17 Kinsella JP, Neish SR, Shaffer E, Abman SH. Low-dose inhalational nitric oxide in persistent pulmonary hypertension of the newborn. Lancet 1992;340:819-20

18 Finer NN, Etches PC, Kamstra B, Tierney AJ, Peliowski A, Ryan CA. Inhaled nitric oxide in infants referred for extracorporeal membrane oxygenation: dose response. F Pediatr 1994;124:302-8.

19 The NINOS Study Group: Inhaled nitric oxide for near-term infants with respiratory failure. N Engl f Med 1997:336:597-604.

20 Kinsella JP, Truog WE, Walsh WF, Goldberg RN, Bancalari E, Clark RH, et al. Randomized, multicenter trial of inhaled nitric oxide and high frequency ventilation in severe persistent pulmonary hypertension of the newborn. Pediatr Res 1996;39:222A.

21 Wessel D, Adatia I, Thompson J, Kane J, van Marter L, Stark A, et al. Improved oxygenation in a randomized trial of inhaled nitric oxide for PPHN. Pediatr Res 1996:39:252A

22 Roberts JD Jr., Fineman J, Morin FC III, Shaul PW, Rimar S, Schreiber $\mathrm{MD}$, et al. Inhaled nitric oxide gas improves oxygenation in PPHN. Pediatr Res 1996;39:241A.

23 Day RW, Lynch JM, White KS, Ward RM. Acute response to inhaled nitric oxide in newborns with respiratory failure and pulmonary hypertension. Pediatrics 1996;98:698-705.

24 Goldman AP, Tasker RC, Haworth SG, Sigston PE, Macrae DJ. Four patterns of response to inhaled nitric oxide for persistent pulmonary hypertension of the newborn. Pediatrics 1996;98:706-13.

25 Wagenvoort CA. Misalignment of lung vessels: a syndrome causing persistent neonatal pulmonary hypertension. Hum Pathol 1986;17:727-30. 
26 Steinhorn RH, Cox PN, Fineman R, Finer NN, Rosenberg EM, Silver MM, et al. Inhaled nitric oxide enhances oxygengation but not survival in infants

27 Barefield ES, Karke VA, Phillips JB, Carlo WA. Inhaled nitric oxide in term infants with hypoxemic respiratory failure. F Pediatr 1996;129:279-86.

28 The Neonatal Inhaled Nitric Oxide Study (NINOS) Group. Inhaled nitric oxide and hypoxic respiratory failure in infants with congenital diaphragmatic hernia. Pediatrics 1997;99:838-45.

29 Kinsella JP, Neish SR, Dunbar I, Shaffer E, Abman SH. Clinical responses to prolonged treatment of persistent pulmonary hypertension of the newborn with low doses of inhaled nitric oxide. F Pediatr 1993;123:103-8.

30 Karamanoukian $\mathrm{H}$, Glick $\mathrm{P}$, Zayek $\mathrm{M}$, et al. Inhaled nitric oxide in congenital hypoplasia of the lungs due to diaphragmatic hernia or oligohydramnios. Pediatrics 1994;94:715.

31 Shah N, Jacob T, Exler R, Morrow S, et al. Inhaled nitric oxide in congenital diaphragmatic hernia. F Pediatr Surg 1994;29:101-15.

32 Frostell CG, Lonnqvist PA, Sonesson SE, et al. Near fatal pulmonary hypertension after surgical repair of congenital diaphragmatic hernia. Anesthesia 1993;48:679-83.

33 Henneberg SW, Jepsen S, Andersen PK, Pedersen SA. Inhalation of nitric oxide as a treatment of pulmonary hypertension in congenital diaphragoxide as a treatment of pulmonary hyperten
matic hernia. F Pediatr Surg 1995;30:853-5.

34 Stahlman M, Blankenship WJ, Shepard FM, et al. Circulatory studies in clinical hyaline membrane disease. Biol Neonate 1972;20:300-20.

35 Walther FJ, Benders MJ, Leighton JO. Persistent pulmonary hypertension in premature neonates with severe respiratory distress syndrome. Pediatrics 1992;90:899-904

36 Skinner JR, Boys RJ, Hunter S, Hey EN. Pulmonary and systemic arterial pressure in hyaline membrane disease. Arch Dis Child 1992;67:366-73.

37 Abman S, Kinsella JP, Schaffer MS, Wilkening RB. Inhaled nitric oxide in the management of a premature newborn with severe respiratory distress and pulmonary hypertension. Pediatrics 1993;92:606-9.

38 Peliowski A, Finer NN, Etches PE, Tierney AJ, Ryan CA. Inhaled nitric oxide for premature infants after prolonged rupture of the membranes. $\mathcal{F}$ Pediatr 1995;126:450-3.

39 Skimming JW, Bender KA, Hutchison AA, Drummond WH. Nitric oxide inhalation increases blood oxygen levels of infants with respiratory distress syndrome. Pediatr Res 1996;39:245A.

40 Miller OI, Celemajer DS, Deanfeild JE, Macrae DJ. Very-low-dose inhaled nitric oxide: A selective pulmonary vasodilator after operations for nitric oxide: A selective pulmonary vasodilator after operation

41 Roberts JD, Lang P, Bigatello LM, Vlahakes GJ, Zapol WM. Inhaled nitric oxide in congenital heart disease. Circulation 1993;87:447-53.

42 Morita K, Ihnken K, Buckberg GD, Sherman MP, Ignarro LJ. Pulmonary vasoconstriction due to impaired nitric oxide production after cardiopulmonary bypass. Ann Thorac Surg 1996;61:1775-80.

43 Wessel, DL, Adatia, I, Giglia, TM. Use of inhaled nitric oxide and acetylcholine in the evaluation of pulmonary hypertension and endothelial function after cardiopulmonary bypass. Circulation 1993;88:2128.

44 Miller OI, Tang SF, Keech A, Celermajer DS. Rebound pulmonary hypertension on withdrawal from inhaled nitric oxide. Lancet 1995;345:51-2.

45 Lavoie A, Hall JB, Olson DM, Wylam ME. Life-threatening effects of discontinuing inhaled nitric oxide in severe respiratory failure.
Crit Care Med 1996;153:1985-7.

46 Atz AM, Adatia I, Wessel DL. Rebound pulmonary hypertension after inhalation of nitric oxide. Ann Thorac Surg 1996;62:1759-64

47 Goldman AP, Tasker RC, Cook P, et al. Transfer of critically ill patients with inhaled nitric oxide. Arch Dis Child 1995;73:F480.

48 Kinsella JP, Schmidt JM, Griebel J, Abman SH. Inhaled nitric oxide treatment for stabilization and emergency medical transport of critically ill newborns and infants. Pediatrics 1995;95:773-6.

49 Ambrosi P, Faugere G, Poggi L. Paradoxical effect of inhaled nitric oxide in a newborn with pulmonary hypertension. Lancet 1993;342:364-5.

50 Oriot D, Boussemart T, Berthier M, Bonneau D, Coisne D. Paradoxical effect of inhaled nitric oxide in a newborn with pulmonary hypertension. Lancet 1993;342:364-5.

51 Austin AT. The chemistry of the higher oxides of nitrogen as related to the manufacture, storage and administration of nitrous oxide. $\mathrm{Br} \mathcal{F}$ Anaesth 1967;39:345-50.
52 Greenbaum R, Bay J, Hargreaves MD, Kain ML, Kelman GR, Nunn JF, et al. Effects of higher oxides of nitrogen on the anaesthetized dog. $\mathrm{Br} \mathrm{F}$

53 Stavert DM, Lehnert BE. Nitric oxide and nitrogen dioxide as inducers of acute pulmonary injury when inhaled at relatively high concentrations for brief periods. Inhal Toxic 1990;2:53-67.

54 Stephens RJ, Freeman G, Evans MJ. Early response of lungs to low levels of nitrogen dioxide. Arch Environ Health 1972;24:160-79.

55 Rasmussen TR, Kjaergaard SK, Tarp U, Pedersen OF. Delayed effects of $\mathrm{NO} 2$ exposure on alveolar permeability and glutathione peroxidase in healthy humans. Am Rev Respir Dis 1992;146:654-9.

56 National Institute for Occupational Safety and Health. NIOSH recommendations for occupational safety and health standards. Morbid Mortal Weekly Rep 1988;37:21

57 Threshold limit values and biological exposure indices for 1989-90. American Conference of Governmental Industrial Hygieniests. Cincinnati, $\mathrm{OH}: 1989$.

58 Bouchet M, Renaudin MH, Raveau C, Mercier JC Dehan M, Zupan V. Safety requirement

59 Beckman JS, Beckman TW, Chen J, Marshall PA, Freeman BA Apparent hydroxyl radical production by peroxynitritie: Implications for endothelial hydroxyl radical production by peroxynitritie: Implications for endothelial injury from nitric

60 Haddad IY, Ischiropoulos H, Holm BA, Beckman JS, Baker JR, Matalon S. Mechanisms of peroxynitrite-induced injury to pulmonary surfactants. $\mathrm{Am}$ F Physiol 1993; 265:

61 Hallman M, Bry K. Nitric oxide and surfactant. Semin Perinatol 1996;20:173-85.

62 Radomski MW, Moncada S. Regulation of vascular homeostasis by nitric oxide. Thromb Haemostas 1993;70:36-41.

63 Hogman M, Frostell C, Arnberg H, Sandhagen B, Hedenstierna G. Prolonged bleeding time during nitric oxide inhalation in the rabbit. Acta Physiologica Scandinavica 1994;151:125.

64 Hogman M, Frostell C, Arnberg H, Hedenstierma G. Bleeding time prolongation and NO inhalation. Lancet 1993;341:1664-5.

65 Benzing A, Brautigam MD, Geiger MD, et al. Inhaled nitric oxide reduces pulmonary transvascular album

66 Cooke JP, Tsao PS Cytoprotective effect of nitric oxide. Circulation 1993;88:2451-4

67 Barbotin-Larrieu F, Mazmanian M, Baudet B, et al. Prevention of ischemiareperfusion lung injury by inhaled nitric oxide in neonatal piglets. $\mathcal{F} A p p l$ Physiol 1996;80:782-8.

68 Gessler P, Nebe T, Birle A, Mueller W, Kachel W. A new side effect of inhaled nitric oxide in neonates and infants with pulmonary hypertension: functional impairment of the neutrophil respiratory burst. Int Care Med 1996;22:252-8

69 Guidot DM, Hybertson BM, Kitlowski RP, Repine JE. Inhaled NO prevents IL-1-induced neutrophil accumulation and associated acute edema in isolated rat lungs. Am $\mathcal{7}$ Physiol 1996;15:L225-L9.

70 Schedin U, Norman M, Gustafsson LE, Herin P, Frostell,C. Endogenous nitric oxide in the upper airways of healthy newborn infants. Pediatr Res

71 Gerlach H, Rossaint R, Pappert D. Autoinhalation of nitric oxide after endogenous synthesis in nasopharynx. Lancet 1994;343:518.

72 Thusu KG, Morin FC, Russell JA, Steinhorn RH. The cGMP phosphodiesterase inhibitor zaprinast enhances the effect of nitric oxide. Am f Respir Crit Care Med 1995;152:1605-10.

73 Kinsella JP, Torielli F, Ziegler JW, et al. Dipyridamole augmentation of response to nitric oxide. Lancet 1995;346:647.

74 Zobel G, Dacar G, Rodl S, et al. Inhaled nitric oxide versus inhaled prostacyclin and intravenous versus inhaled prostacyclin in acute respiratory failure with pulmonary hypertension in piglets. Pediatr Res 1995;38:198-204.

75 Curtis J, O'Neill JT, Pettett G. Endotracheal administration of tolazoline in hypoxia-induced pulmonary hypertension. Pediatrics 1993:92;403-8. 